\title{
PENINGKATAN KETRAMPILAN MENULLIS PERMULAAN DENGAN MENGGUNAKAN MEDIA KARTU HURUF PADA SISWA KELAS I SD NEGERI GAMER 02 KOTA PEKALONGAN
}

\author{
Qodaroh \\ SDN Gamer 02 Pekalongan
}

\begin{abstract}
Abstrak
Masalah yang diangkat pada penelitian adalah rendahnya ketrampilan menulis permulaan kelas I SD Negeri Gamer 02 Kota Pekalongan. Pembelajaran mengalami hambatan karena siswa kurang tertarik apabila diberi pekerjaan rumah berupa tugas menulis. Adapun bila ada waktu luang, mereka lebih memilih untuk menonton televisi, maupun bermain. Disamping itu juga Adanya sugesti terhadap kebosanan siswa dalam belajar menulis terjadi karena penanaman cara mengajar keterampilan menulis yang tidak bervariasi atau monoton. Untuk mengatasinya digunakan Media Kartu Huruf untuk meningkatkan ketrampilan menulis permulaan. Pada siklus I diperoleh hasil rata-rata kelas sebesar 62,92 dalam kategori cukup. Setelah dilakukan tindakan pada siklus II diperoleh rata-rata kelas sebesar 82,13 dalam kategori baik atau mengalami peningkatan sebesar 18,75 atau 30,27\%. Perilaku siswa kelas I SD Negeri Gamer 02 Kota Pekalongan selama mengikuti pembelajaran menulis permulaan dengan menggunakan media kartu huruf mengalami perubahan ke arah yang lebih positif. Perilaku tersebut yaitu siswa mampu menunjukkan sikap antusias selama proses pembelajaran, siswa lebih aktif selama proses pembelajaran, siswa lebih berani dan percaya diri mempresentasikan hasil diskusi, siswa lebih termotivasi untuk menulis permulaan.
\end{abstract}

Kata kunci: Ketrampilan menulis permulaan, media kartu huruf 


\section{PENDAHULUAN}

Keterampilan menulis sebagai salah satu keterampilan berbahasa sangatlah penting untuk dikuasai. Pentingnya penguasaan keterampilan menulis di era teknologi canggih seperti sekarang ini dikarenakan melalui tulisan orang dapat mengungkapkan ide dan gagasannya tanpa harus bertatap muka secara langsung dengan orang lain atau pembaca. Dengan adanya teknologi pula, tulisan dapat menembus ruang dan waktu. Artinya, tulisan dapat dibaca oleh orang yang berada ditempat yang jauh dari penulis tulisan tersebut tanpa atau dengan mengetahui siapa penulisnya.

Keberhasilan tersebut dapat dilihat dari tercapainya indikator secara maksimal. Begitu juga dengan keterampilan menulis Menulis Permulaan dengan cara menjiplak, menebalkan, mencontoh, melengkapi dan menyalin dianggap berhasil, jika indikator yang disampaikan te rcapai dengan maksimal. Adanya sugesti terhadap kebosanan siswa dalam belajar menulis terjadi karena penanaman cara mengajar keterampilan menulis yang tidak bervariasi atau monoton. Kemonotonan ini adalah momok yang perlu dibenahi oleh revolusioner di bidang menulis terutama guru yang bertindak sebagai orang terdekat siswa setelah orang tua yang lebih bersinggungan langsung dengan keterampilan ini.

Berdasarkan observasi diperoleh data bahwa siswa Kelas I SD Negeri Gamer 02 Kota Pekalongan keterampilan menulis kalimat permulaan masih rendah. Ini terbukti dengan adanya sebagian besar siswa yaitu 25 dari 32 siswa (75\%) yang dapat menulis ketika mendapatkan tugas dari guru. Di samping itu diakui, bahwa siswa kurang tertarik apabila diberi pekerjaan rumah berupa tugas menulis. Adapun bila ada waktu luang, mereka lebih memilih untuk menonton televisi, maupun bermain. Dalam observasi tersebut juga ditemukan permasalahan lain.

Peneliti yang melakukan observasi langsung di kelas I SD Negeri Gamer 02
Kota Pekalongan, menemukan data dari 32 siswa 5 siswa mendapatkan nilai 100-85, 8 siswa mendapatkan nilai 84-70, dan 19 siswa mendapatkan nilai 69 ke bawah. Dari hal ini menunjukan bahwa siswa kelas I belum dapat menguasai keterampilan menulis permulaan, sehingga kompetensi yang diharapkan belum tercapai. Rendahnya kemampuan menulis siswa dapat dilihat dari banyaknya siswa yang mendapatkan di bawah kriteria ketuntasan minimal (KKM) di kelas I SD Negeri Gamer 02 Kota Pekalongan, yaitu 70, Hal ini menunjukan bahwa keterampilan menulis siswa kelas I SD Negeri Gamer 02 Kota Pekalongan masih rendah.

Berdasarkan penelitian yang telah dilakukan, pembelajaran Bahasa Indonesia pada Siswa kelas I SD Negeri Gamer 02 Kota Pekalongan belum menunjukan hasil yang diharapkan. Pembelajaran tersebut belum menunjukan hasil yang diharapkan karena beberapa faktor, yakni faktor internal maupun eksternal.

Secara internal, rendahnya kemampuan siswa dalam menulis disebabkan kurangnya latihan dan motivasi dari dalam diri siswa itu sendiri, siswa sering muncul sifat ketergantungan orang lain, disini guru atau orang tua sehingga menimbulkan kemalasan untuk berlatih pada siswa.

Selain faktor internal tersebut faktor eksternal juga sangat berpengaruh terhadap keberhasilan pembelajaran Bahasa Indonesia sesuai yang diharapkan. Kebanyakan siswa menganggap bahwa Bahasa Indonesia adalah pembelajaran yang membosankan, sehingga siswa enggan untuk belajar dan menyebabkan siswa kurang latihan atau malas berlatih. Pola pengajaran guru juga sangat berpengaruh terhadap keberhasilan pembelajaran Bahasa Indonesia. Pembelajaran yang hanya menggunakan metode atau media pembelajaran tidak mendukung atau kurang menarik dan efesien biasanya membuat siswa kurang tertarik untuk mengikuti pembelajaran. 
Dari hal-hal tersebut di atas perlu upaya untuk mengubah perilaku terhadap pembelajaran Menulis permulaan dengan menjiplak, menebalkan, mencontoh, melengkapi dan menyalin pada Mata Pelajaran Bahasa Indonesia sehingga dapat meningkatkan hasil belajar siswa. Guru harus dituntut senantiasa mampu menuntun dah mengarahkan pelaksanaan pembelajaran sehingga terjadi kesinambungan maupun umpan balik pembelajaran antara guru dan siswa. Kartu huruf adalah salah satu Media Pembelajaran yang diharapkan dapat meningkatkan kemampuan maupun ketrampilan menulis siswa kelas I SD Negeri Gamer 02 Pekalongan.

\section{KAJIAN PUSTAKA DAN LANDASAN TEORETIS}

Penelitian tindakan kelas tentang menulis merupakan penelitian yang menarik. Hal tersebut dibuktikan dengan banyaknya penelitian yang dilakukan oleh peneliti berkenaan dengan topik penelitian ini antara lain Ikeguchi (1997), Kesper (1997), Asrikah (2008), Zaenudin (2009), Permana (2010), Basarrudin (2010), Puspitasari (2011), dan Hellwig (2011).

Ikeguchi (1997) dalam penelitiannya yang berjudul Pengajaran Keterampilan Menulis Terpadu, menunjukkan bahwa proses pembelajaran menulis terpadu sangat efektif digunakan oleh mahasiswa Jepang dalam kelas menulis. Dengan pembelajaran menulis terpadu, mahasiswa dilatih untuk menempatkan ide-ide secara logis, mengatur pola pikir mereka, dan mengekspresikan ide-ide tersebut dalam kalimat lengkap. Teknik ini memberikan kebebasan kepada mahasiswa untuk mengekspresikan diri untuk dapat menghasilkan tulisan terbaik.

Penelitian yang dilakukan oleh Ikeguchi mempunyai keterkaitan dengan penelitian yang dilakukan peneliti, yaitu sama-sama meneliti keterampilan menulis. Namun, aspek penelitian, tingkat pendidikan, dan subjek penelitian yang digunakan berbeda. Ikeguchi melakukan penelitian keterampilan menulis secara umum pada tingkat perguruan tinggi, sedangkan peneliti melakukan penelitian keterampilan menulis pada tingkat SD.

Senada dengan penelitian yang dilakukan Erlinawati.2009. dengan judul "Meningkatkan Pembelajaran Membaca Menulis Permulaan dengan Model Kartu Huruf di Kelas I SD Negeri Kemiri Kecamatan Puspo Kabupaten Pasuruan. “

Kemampuan membaca menulis merupakan landasan utama untuk menimba ilmu pengetahuan. Untuk itu kemampuan membaca menulis perlu diterapkan sejak dini. Berdasarkan hasil observasi di kelas I SDN Kemiri, kemampuan berbahasa Indonesia khususnya kemampuan membaca menulis permulaan perlu diadakan perbaikan proses pembelajaran guna meningkatkan kemampuan membaca menulis. Ruang lingkup penelitian ini meliputi aktifitas guru dan siswa dalam pelaksanaan pembelajaran membaca dan menulis permulaan dengan media kartu huruf. Obyek penelitian hanya pada siswasiswi kelas I SDN Kemiri kemiri semester ganjil tahun pelajaran 2008-2009.

Hal yang diteliti mengenai keberhasilan pembelajaran membaca menulis permulaan dengan menggunakan media kartu huruf . Penelitian ini bertujuan untuk mendiskripsikan proses pembelajaran membaca menulis permulaan dengan model kartu huruf dan perkembangan kemampuan membaca menulis permulaan.

Hasil penelitian menunjukkan bahwa pembelajaran membaca menulis permulaan dengan model kartu huruf dapat mempermudah pemahaman siswa akan huruf-huruf sehingga mempermudah untuk merangkai suku kata, kata, dan kalimat. Penelitian dilakukan pada 40 siswa, hasil penelitian menunjukkan peningkatan ratarata pada siklus I sebesar $40,2 \%$ ( kegiatan pra siklus I ) meningkat menjadi 63,25. Pada siklus II menunjukkan peningkatan prosentase dari $63,2 \%$ (kategori sedang ) menjadi $72,1 \%$ (kategori baik). Sedangkan dari hasil observasi pada siklus I dan siklus 
II siswa menyukai pembelajaran membaca menulis menggunakan media kartu huruf, hal ini ditunjukkan dengan $50 \%$ pada siklus I siswa dalam kategori baik, dan 55\% siswa pada siklus II dalam kategori baik sekali.

Selain hasil belajar dan observasi, dan wawancara dengan guru dan siswa kelas 1 menunjukkan peningkatan prestasi belajar yang berarti, hal ini terbukti siswa lebih menyukai model kartu huruf karena merasa belajar sambil bermain.

Meskipun telah banyak penelitian mengenai penigkatan membaca menulis permulaan, peneliti masih menganggap perlu dilakukan penelitian sejenis. Hal ini dikarenakan kenyataan di lapangan bahwa keterampilan membaca menulis permulaan dikalangan siswa masih kurang dan perlu menggunakan strategi belajara yang tepat dalam pembelajarannya. Dengan alasan tersebut peneliti mengembangkan dengan menggunakan strategi belajar lain yang sekiranya mampu membantu meningkatkan keterampilan siswa dalam membaca menulis permulaan.

Penelitian dengan menggunakan media kartu huruf ini menjadi tolak ukur dan sebagai upaya memperkaya strategi belajar pembelajaran membaca menulis permulaan di sekolah. Oleh karena itu yang menjadi pembeda penelitian ini memuat sejumlah persoalan mendasar tentang masih rendahnya keterampilan membaca menulis permulaan bagi siswa. Baik dari faktor guru, metode pembelajaran, media pembelajaran, maupun dari siswa itu sendiri.Media Kartu Huruf yang digunakan dalam penelitian ini dipandang mampu meningkatkan keterampilan menulis permulaan. Hal ini dikarenakan strategi belajar ini melatih siswa untuk dapat belajar atas kemauan dan kemampuan diri sendiri (pembelajaran mandiri).

Peningkatan keterampilan menulis permulaan dengan menggunakan Media Kartu Huruf berkedudukan sebagai tindak lanjut dan pelengkap dari penelitianpenelitian sebelumnya. Dengan penggunaan strategi belajar ini diharapkan dapat menjadi alternatif bagi guru dalam pembelajaran. Selain itu, dengan adanya penelitian ini diharapkan dapat mengubah perilaku siswa ke arah lebih positif dalam mengikuti pembelajaran menulis permulaan kelas I SD Negeri Gamer 02 Kota Pekalongan. Dengan demikian, dapat disimpulakan bahwa penelitian yang dilakukan oleh peneliti bersifat melengkapi penelitian-penelitian sebelumnya.

Kajian teoritis yang dignakan sebagai kerangka teoritis dalam penelitian adalah Hakikat Menulis, Pengertian Menulis Permulaan, Kegiatan Pembelajaran dengan media pembelajaran dan pengertian serta penerapan media kartu huruf dalam pembelajaran. Sudarwan Danim (2010: 23) dalam bukunya memaparkan bahwa menulis merupakan salah satu sisi dari keterampilan berbahasa. Oleh karena sifatnya demikian, maka latihan yang kontinu menjadi persyaratan. Penulis harus memiliki banyak pengalaman dan kosakata. Penulis harus mampu membahasakan pengalamannya dengan memilih kosakata yang tepat dan merangkainya secara baik dan benar.

Pembelajaran keterampilan menulis permulaan di kelas satu dan dua SD sangat dipengaruhi oleh keterampilan membaca yang telah dikuasai oleh siswa. Siswa tidak akan dapat menulis dengan baik bila siswa belum bisa membaca dengan baik. Hal tersebut juga berlaku sebaliknya di mana siswa tidak akan mampu membaca dengan baik apabila ia belum dapat menulis dengan baik.

Media yang digunakan adalah dengan menggunakan Kartu huruf.

Kartu huruf dapat juga diartikan media yang dibuat oleh pabrik atau buatan sendiri sesuai kreatifitas guru berbentuk potongan yang berisikan gambaran atau tulisan dan bersifat menyampaikan komunikasi atau stimulus pembelajaran kepada anak. Berdasarkan uraian di atas, dapat dikatakan bahwa yang dimaksud kartu huruf adalah media pembelajaran 
visual yang merupakan alat permainan untuk mengembangkan aspek kognitif, psikomotor dan melatih ketrampilan berbahasa serta dapat memberikan situasi belajar yang sangat dan menyenangkan.

Hipotesis tindakan dalam penelitian ini adalah dengan menggunakan media kartu bilangan, kemampuan Menulis Permulan kelas I SD Negeri Gamer 2 Kota Pekalongan dapat meningkat dan perilaku siswa dapat berubah ke arah yang lebih positif.

\section{METODE PENELITIAN}

Desain Penelitian tindakan kelas (PTK), yakni penelitian yang berbasis kelas atau sekolah. Penelitian ini dilaksanakan dengan maksud untuk meningkatan kemantapan rasional dari tindakan-tindakan yang dilakukan. Siklus ini terdiri atas empat komponen yaitu: perencanaan, tindakan, observasi, dan refleksi.

Pada Siklus I, perencanaan berupa kegiatan-kegiatan menentukan langkahlangkah yang akan dilakukan untuk memecahkan masalah pada pembelajaran siklus I. Langkah ini merupakan upaya untuk memperbaiki kelemahan dalam proses pembelajaran membaca cepat selama ini. Tahap ini bermanfaat agar pelaksanaan pada tahap tindakan lebih mudah, terarah, dan sistematis. Tindakan yang dilakukan yaitu melaksanakan proses pembelajaran pada siklus I sesuai dengan perencanaan yang disusun.

Pada siklus I, perencanaan berupa kegiatan-kegiatan menentukan langkahlangkah yang akan dilakukan untuk memecahkan masalah pada pembelajaran siklus I. Langkah ini merupakan upaya untuk memperbaiki kelemahan dalam proses pembelajaran menulis maupun membaca selama ini. Tahap ini bermanfaat agar pelaksanaan pada tahap tindakan lebih mudah, terarah, dan sistematis. Tindakan yang dilakukan yaitu melaksanakan proses pembelajaran pada siklus I sesuai dengan perencanaan yang disusun.

Tindakan yang dilakukan yaitu melaksanakan proses pembelajaran menulis permulaan. Observasi dilakukan untuk mengetahui segala peristiwa yang berhubungan dengan pembelajaran maupun respon terhadap teknik dan media yang digunakan oleh guru. Data observasi diperoleh dari lembar observasi, catatan harian guru, catatan harian siswa, lembar wawancara, dan dokumentasi foto. Refleksi bertujuan untuk mengetahui kendala apa yang ditemui dalam meningkatkan pemahaman dan ketrampilan menulis permulaan.

Pada siklus II, perencanaan adalah penyempurnaan dari perencanaan siklus I. Hasil refleksi siklus I guru melakukan perencanaan ulang. Tindakan yang dilakukan adalah dengan perencanaan yang telah disusun berdasarkan perbaikan pada siklus I. Materi pembelajarn sama seperti materi pembelajaran siklus I, yaitu menulis permulaan dengan menggunakan media kartu bilangan. Tahap tindakan dilaksanakan dalam tiga tahap, yaitu tahap persiapan, tahap pelaksanaan, dan tahap tindak lanjut. Observasi dilakukan untuk mengumpulkan data tentang pembelajaran menulis permulaan. Pengambilan data dilakukan dengan teknik tes dan nontes. Refleksi dilakukan dengan menganalisis hasil tes keterampilan menulis permulaan dan hasil nontes yang dilakukan pada siklus II.

Subjek penelitian tindakan kelas ini adalah menulis permulaan pada siswa kelas I SD Negeri Gamer 02 Kota Pekalongan. Variabel penelitian ini menggunakan dua macam variabel, yaitu variabel keterampilan menulis permulaan dengan menggunakan media kartu bilangan. Indikator kinerja dalam penelitian ini meliputi dua yaitu aspek kuantitif dan aspek kualiti. Penelitian ini menggunakan dua teknik pengumpulan data, yaitu teknik tes dan teknik nontes. 
Tes dilakukan dengan menggunakan soal-soal. Tes dilakukan sebanyak dua kali, yaitu pada tes a siklus I dan tes b siklus II. Skor penilaian berdasarkan aspek-aspek yang sudah ada. Tes yang digunakan dalam penelitian ini adalah tes tertulis yang sesuai dengan materi, yaitu ketrampilan menulis permulaan dengan cara melengkapi huruf, kata maupun kalimat. Dalam melakukan tes ini, diperlukan instrumen atau alat bantu yang berupa kriteria atau pedoman penilaian. Penilaian tersebut harus menunjukkan pencapaian indikator yang telah ditentukan. Sedangkan teknik nontes yang digunakan pada penelitian ini adalah lembar observasi, lembar jurnal, lembar wawancara, dan lembar dokumentasi foto yang digunakan untuk mengungkapkan perubahan tingkah laku siswa selama mengikuti pembelajaran menulis permulaan dengan cara melengkapi huruf, kata maupun kalimat.

Analisis data yang dilakukan oleh peneliti pada proses pembelajaran menulis permulaan dengan menggunakan media kartu bilangan adalah teknik kualitatif dan kuantitatif.

\section{HASIL PENELITIAN DAN PEMBAHASAN

Proses Pembelajaran menulis permulaan pada Siklus I}

Proses pembelajaran menulis permulaan menggunakan media kartu huruf, langkah-langkahnya antara lain: 1) intensifnya proses internalisasi penumbuhan minat-minat siswa untuk menulis permulaan, 2) proses diskusi siswa dalam pembelajaran menulis permulaan terlaksana secara kondusif, 3)intensifnya siswa dalam proses menulis permulaan dengan menggunakan kartu huruf, 4) kondusifnya kondisi siswa saat proses pembelajaran, 5) terbangunnya suasana reflektif saat kegiatan refleksi pada akhir pembelajaran sehingga siswa bisa menyadari kekurangan saat proses pembelajaran dan mengetahui apa yang akan dilakukan setelah proses pembelajaran.

Sebanyak 22 siswa dari jumlah keseluruhan 32 anak $(68,75 \%)$ intensifnya proses internalisasi penumbuhan minatminat siswa untuk menulis permulaan. Pada aspek pertama ini tergolong dalam katagori cukup baik. Pada Aspek kedua, sebanyak 23 siswa atau $71,88 \%$ proses diskusi siswa dalam pembelajaran dapat terlaksana secara cukup kondusif. Pada aspek ketiga tergolong dalam katagori cukup baik. Aspek ketiga, intensifnya siswa dalam proses menulis permulaan. Sebanyak 21 siswa atau $71,88 \%$ dan termasuk dalam katagori cukup baik. Aspek keempat, kondusifnya kondisi siswa saat proses pembelajaran. Sebanyak 24 siswa atau $75,00 \%$ dengan katagori cukup baik. Selanjutnya, Aspek kelima terbangunnya suasana reflektif saat kegiatan refleksi pada akhir pembelajaran sehingga siswa bisa menyadari kekurangan saat proses pembelajaran dan mengetahui apa yang akan dilakukan setelah proses pembelajaran. Sebanyak 22 siswa atau 68,75 \% tergolong dalam katagori cukup baik. Sebagian besar siswa memperhatikan guru ketika memberikan masukan dan merefleksi bersama siswa pembelajaran yang telah dilakukan. Ratarata pencapaian aspek pada siklus ini adalah 22,8 atau $71,25 \%$ atau pada katagori cukup.

hasil tes keterampilan menulis permulaan menggunakan media kartu huruf mencapai jumlah nilai 2076, dengan rata-rata 64,88 termasuk dalam kategori cukup. Dari 32 siswa, tidak ada siswa yang memperoleh skor $\leq 49$ atau dalam kategori tidak baik, ada 2 siswa atau $6,25 \%$ yang memperoleh rentang skor antara 85-100 atau dalam kategori sangat baik , 4 siswa atau $12,50 \%$ memperoleh nilai dalam kategori baik dengan rentang skor 70-84, 18 siswa atau $56,25 \%$ memperoleh nilai dalam kategori cukup dengan rentang skor 60-69 dan 8 siswa atau $25 \%$ memperoleh nilai dalam kategori kurang dengan rentang skor 50- 
59. Hasil tersebut merupakan jumlah skor tiga aspek keterampilan menulis permulaan yang telah diujikan yaitu aspek penemuan : (1) Melengkapi huruf, (2) Melengkapi suku kata, (3) Melengkapi kata.

Perubahan perilaku pada sebagian siswa menunjukkan sikap positif dalam pembelajaran menulis permulaan menggunakan media kartu huruf. Dalam pembelajaran menulis permulaan menggunakan media kartu huruf tercatat 23 siswa atau 71,88\% menunjukkan sikap aktif dalam pembelajaran. Sebanyak 23 siswa atau $71,88 \%$ antusias dalam mengikuti pembelajaran, 17 siswa atau $53,13 \%$ siswa berani dan percaya diri untuk mempresentasikan hasil diskusi.

\section{Proses Pembelajaran menulis permulaan pada Siklus II}

Pembelajaran menulis permulaan dengan menggunakan media kartu huruf berlangsung dengan baik. Hal tersebut dibuktikan dengan adanya peningkatan dibandingkan hasil pada siklus I. Tercatat sebanyak 28 siswa dari jumlah keseluruhan 32 anak $(87,5 \%)$ intensif dalam proses internalisasi penumbuhan minat-minat siswa untuk menulis permulaan. Hasil ini mengalami peningkatan dibandingkan pada siklus I sebesar $18,75 \%$ dari angka $68,75 \%$ menjadi $87,50 \%$. Pada aspek pertama ini tergolong dalam katagori sangat baik. Sebanyak 28 siswa atau $87,50 \%$ siswa pada aspek kedua kondusif dalam proses diskusi siswa dalam melengkapi huruf, suku kata ataupun melengkapi kata.

Pada aspek kedua ini mengalami peningkatan sebesar $9,37 \%$ dari angka $71,88 \%$ menjadi $81,25 \%$ dan termasuk dalam katagori baik. Pada aspek ketiga, keintensifan siswa dalam proses menulis permulaan, sebanyak 27 siswa atau $84,38 \%$ dan termasuk dalam katagori baik. Pada aspek ketiga mengalami peningkatan dari $71,88 \%$ sebanyak $12,50 \%$ menjadi $84,38 \%$ dan termasuk dalam katagori baik. Aspek keempat, kondusifnya kondisi siswa saat proses pembelajaran. Sebanyak 28 siswa atau $87,50 \%$ meningkat sebanyak $12,50 \%$ dari $75 \%$ pada siklus I dan termasuk dalam katagori baik. Selanjutnya, Aspek kelima terbangunnya suasana reflektif saat kegiatan refleksi pada akhir pembelajaran sehingga siswa bisa menyadari kekurangan saat proses pembelajaran dan mengetahui apa yang akan dilakukan setelah proses pembelajaran. Sebanyak 26 siswa atau $81,25 \%$ mengalami peningkatan sebanyak $3,12 \%$ dari hasil $78,13 \%$ pada siklus I dan termasuk dalam katagori baik. Sebagian besar siswa memperhatikan guru ketika memberikan masukan dan merefleksi bersama siswa pembelajaran yang telah dilakukan pada siklus II. Ratarata pencapaian aspek pada siklus II adalah 27 atau $84,38 \%$. Hasil ini meningkat sebesar $13,13 \%$ dari siklus I dan termasuk dalam katagori baik.

Hasil tes keterampilan menulis permulaan dengan menggunakan media kartu huruf mencapai jumlah nilai 2.650, dengan rata-rata 82,13 termasuk dalam kategori baik. Dari 32 siswa, 10 siswa mendapatkan nilai 100, 22 siswa memperoleh nilai beragam dalam kriteria 70-84 yang termasuk dalam katagori baik, dan tidak ada siswa yang memperoleh skor $\leq 70$ atau dalam kategori cukup, kurang, maupun tidak baik. Hasil tersebut merupakan jumlah skor empat aspek keterampilan menulis permulaan.

Sebagian siswa menunjukkan sikap positif dalam pembelajaran menulis permulaan dengan menggunakan media kartu huruf. Dalam pembelajaran menulis permulaan dengan menggunakan media kartu huruf tercatat 30 siswa atau $93,75 \%$ menunjukkan sikap aktif dalam pembelajaran. Sebanyak 30 siswa atau $93,75 \%$ antusias dalam mengikuti pembelajaran, 29 siswa atau 90,63\% siswa berani dan percaya diri untuk mempresentasikan hasil diskusi.

\section{Pembahasan}


Tabel 1. Hasil Proses Pembelajaran menulis permulaan pada Siklus I dan Siklus II

\begin{tabular}{|c|c|c|c|c|c|}
\hline \multirow{3}{*}{ Aspek yang diamati } & \multicolumn{4}{|c|}{ Rata-Rata Skor } & \multirow{3}{*}{$\begin{array}{c}\text { Pening- } \\
\text { katan } \\
(\%)\end{array}$} \\
\hline & \multicolumn{2}{|c|}{ Siklus I } & \multicolumn{2}{|c|}{ Siklus II } & \\
\hline & $\mathrm{F}$ & (\%) & $\mathrm{F}$ & $(\%)$ & \\
\hline $\begin{array}{ll}\text { 1. Intensifnya } \\
\text { proses } \\
\text { internalisasi } \\
\text { penumbuhan } \\
\text { minat-minat } \\
\text { siswa untuk }\end{array}$ & 22 & 68,75 & 28 & 87,5 & 18,75 \\
\hline $\begin{array}{ll}2 . & \text { Proses diskusi } \\
& \text { siswa dalam } \\
\text { pembelajaran } \\
\text { dapat terlaksana } \\
\text { secara kondusif }\end{array}$ & 23 & 71,88 & 26 & 81,25 & 9,37 \\
\hline $\begin{array}{ll}3 . & \text { Intensifnya siswa } \\
& \text { dalam proses } \\
& \text { menulis } \\
\text { permulaan }\end{array}$ & 23 & 71,88 & 27 & 84,35 & 12,47 \\
\hline $\begin{array}{ll}\text { 4. } & \text { Kondusifnya } \\
\text { kondisi siswa } \\
\text { saat proses } \\
\text { pembelajaran }\end{array}$ & 24 & 75,00 & 28 & 87,50 & 12,50 \\
\hline $\begin{array}{ll}5 . & \text { Terbangunnya } \\
& \text { suasana reflektif } \\
& \text { saat kegiatan } \\
& \text { refleksi pada } \\
& \text { akhir }\end{array}$ & 22 & 78,13 & 26 & 81,25 & 3,12 \\
\hline Rata - rata & & 71,25 & & 84,38 & 13,13 \\
\hline
\end{tabular}

Berdasarkan Tabel 1 diketahui proses pembelajaran dalam pembelajaran menulis permulaan dengan menggunakan media kartu huruf meningkat dari siklus I ke siklus II. Dalam pembelajaran menulis permulaan dengan menggunakan media kartu huruf pada siklus I tercatat 22 siswa atau $68,75 \%$ siswa berminat untuk menulis permulaan, dan pada siklus II mengalami peningkatan $18,75 \%$ menjadi 28 siswa atau 87,50\%, pada siklus I 23 siswa atau $71,88 \%$ mampu melakukan proses diskusi dengan baik sehingga suasana diskusi berlangsung kondusif, dan pada siklus II mengalami peningkatan sebesar 9,37\% menjadi 26 siswa atau
$81,25 \%$, pada siklus I tercatat 23 siswa atau $71,88 \%$ siswa mampu intensif dalam proses menulis permulaan, pada siklus II meningkat $12,47 \%$ menjadi 27 siswa atau $84,35 \%$, siklus I tercatat 24 siswa atau $75,00 \%$ mampu kondusif dalam pembelajaran, dan pada siklus II meningkat sebesar $12,50 \%$ menjadi 28 siswa atau $87,50 \%$, dan saat kegiatan refleksi pada siklus I tercatat 22 siswa atau $78,13 \%$ mampu membangun suasana reflektif ketika kegiatan refleksi berlangsung, dan terjadi peningkatan juga pada siklus II sebesar 3,12\% menjadi 26 siswa atau $81,25 \%$.

Tabel 2. Hasil Tes Keterampilan Menulis permulaan Siklus I dan Siklus II

\begin{tabular}{|c|l|c|c|c|c|}
\hline \multirow{2}{*}{ No } & \multirow{2}{*}{ Aspek Penilaian } & \multicolumn{2}{|c|}{$\begin{array}{c}\text { Rata-rata } \\
\text { Skor }\end{array}$} & \multicolumn{2}{c|}{ Peningkatan } \\
\cline { 3 - 6 } & & SI & SII & SII-SI & $\begin{array}{c}\text { Persen } \\
(\%)\end{array}$ \\
\hline 1. & Melengkapi Huruf & 68,13 & 86,25 & 18,12 & 26,56 \\
\hline 2. & $\begin{array}{l}\text { Melengkapi Suku } \\
\text { Kata }\end{array}$ & 64,38 & 80,00 & 15,62 & 24,26 \\
\hline 3. & Melengkapi Kata & 56,25 & 78,75 & 22,5 & 40,00 \\
\hline \multicolumn{2}{|l|}{ Nilai Rata-rata Klasikal } & 62,92 & 82,13 & 18,75 & 30,27 \\
\hline
\end{tabular}

Hasil tes keterampilan menulis permulaan dengan mnggunakan media kartu huruf mengalami peningkatan dari siklus I ke siklus II sebesar 18,75 atau $30,27 \%$ yaitu dari nilai rata-rata kelas pada siklus I sebesar 62,92 menjadi sebesar 82,13 pada siklus II.

Hasil tes keterampilan menulis permulaan siklus I dan siklus II dapat dijelaskan bahwa permulaan pada tiap aspek mengalami peningkatan. Rata-rata skor pada aspek Melengkapi huruf pada siklus I mencapai rata-rata 68,13 dan setelah dilakukan pembelajaran siklus II skor rata-rata mencapai 86,25, meningkat 18,12 atau sebesar 26,56\%. Pada aspek Melegkapi suku kata skor rata-rata yang diperoleh pada siklus I mencapai 64,38 dan setelah pembelajaran siklus II mencapai 80,00 meningkat 
15,62 atau sebesar 24,26\%. Pada aspek Melengkapi kata skor rata-rata yang diperoleh pada siklus I mencapai 56,25 dan setelah pembelajaran siklus II mencapai 78,75 meningkat 22,50 atau sebesar $40,00 \%$.

Peningkatan keterampilan menulis permulaan dengan menggunakan media kartu huruf kelas I SD Negeri Gamer 02 Kota Pekalongan merupakan suatu prestasi yang patut dibanggakan. Keberhasilan yang dicapai siswa sangat memuaskan. Sebelum dilakukan tindakan pembelajaran menulis permulaan dengan menggunakan media kartu huruf, sebagian besar nilai siswa belummencapai KKM yang ditentukan. Siswa beranggapan bahwa ketrampilan menulis kurang bahkan susah serta membosankan. Selama ini pembelajaran hanya diberikan guru belum menggunakan media yang inovatif.

Tabel 3. Perilaku Siswa setelah Mengikuti Pembelajaran Siklus I dan Siklus II

\begin{tabular}{|c|c|c|c|c|c|}
\hline \multirow{3}{*}{ Aspek yang diamati } & \multicolumn{4}{|c|}{ Rata-rata Skor } & \multirow{3}{*}{$\begin{array}{c}\text { Pening- } \\
\text { katan } \\
(\%)\end{array}$} \\
\hline & \multicolumn{2}{|c|}{ Siklus I } & \multicolumn{2}{|c|}{ Siklus II } & \\
\hline & $\mathrm{F}$ & $(\%)$ & $\mathrm{F}$ & $(\%)$ & \\
\hline 1. Keantusiasan siswa & 23 & 71,88 & 30 & 93,75 & 21,87 \\
\hline 2. $\quad$ Keaktifan siswa & 23 & 71,88 & 30 & 93,75 & 21,87 \\
\hline $\begin{array}{l}\text { 3. } \\
\text { Keberanian dan } \\
\text { kepercayaan diri } \\
\text { siswa } \\
\text { mempresentasikan } \\
\text { hasil diskusi } \\
\end{array}$ & 17 & 53,13 & 29 & 90,63 & 37,50 \\
\hline Rata-rata Klasikal & 21 & 65,63 & 29,67 & 92,72 & 27,09 \\
\hline
\end{tabular}

Sebagian siswa menunjukkan peningkatan sikap positif dalam pembelajaran menulis permulaan dengan menggunakan media kartu huruf dari siklus I ke siklus II. Dalam pembelajaran menulis menulis permulaan dengan menggunakan media kartu huruf pada aspek keantusiasan siswa pada siklus I tercatat 23 siswa atau $71,88 \%$ menunjukkan sikap aktif dan mengalami peningkatan pada siklus II sebesar 21,87\% yaitu menjadi 30 siswa atau 93,75\%, Aspek keaktifan siswa pada siklus I tercatat 23 siswa atau $71,88 \%$ menunjukkan sikap aktif dan mengalami peningkatan pada siklus II sebesar $21,87 \%$ yaitu menjadi 30 siswa atau $93,75 \%$, sedangkan keberanian dan kepercayaan diri siswa pada siklus I tercatat 17 siswa atau $53,13 \%$ menunjukkan sikap aktif dan mengalami peningkatan pada siklus II sebesar 37,50\% yaitu menjadi 29 siswa atau $90,63 \%$.

\section{SIMPULAN DAN SARAN Simpulan}

Berdasarkan hasil analisis, rumusan masalah, dan pembahasan penelitian tindakan kelas ini, dapat disimpulkan sebagai berikut.

1) Proses pembelajaran Menulis Permulaan dengan menggunakan media kartu huruf pada kelas I SD Negeri Gamer 02 Kota Pekalongan sudah berjalan dengan baik dan lancar sesuai dengan rencana pelaksanaan pembelajaran (RPP). Proses pembelajaran Menulis Permulaan dengan Menggunakan Media Kartu Huruf, yaitu: (1) intensifnya proses internalisasi penumbuhan minat-minat siswa untuk menulis Permulaan, (2) kondusifnya proses diskusi siswa dalam pembelajaran Menulis Permulaan, (3) kondusifnya kondisi siswa saat proses pembelajaran Menulis Permulaan, dan (4) terbangunnya suasana yang sangat reflektif ketika kegiatan refleksi.

2) Ketrampilan menulis permulaan pada siswa kelas I SD Negeri Gamer 02 Kota Pekalongan mengalami peningkatan setelah mengikuti pembelajaran menulis permulaan dengan menggunakan kartu huruf. Peningkatan itu terlihat dari hasil tes menulis permulaan antara siklus I dan siklus II. Pada siklus I diperoleh hasil ratarata kelas sebesar 62,92 dalam kategori cukup. Setelah dilakukan tindakan pada siklus II diperoleh rata-rata kelas sebesar 82,13 dalam kategori baik atau mengalami peningkatan sebesar 18,75 atau 30,27\%. Rata-rata tiap aspek seperti aspek 
melengkapi huruf dari 68,13 menjadi 86,25 mengalami peningkatan 18,12 atau 26,56\%, aspek Melengkapi suku kata dari 64,38 menjadi 80,00 mengalami peningkatan 15,62 atau $24,26 \%$, dan aspek Melengkapi kata dengan nilai 56,25 menjadi 78,75 meningkat 22,50 atau $40 \%$.

3) Perilaku siswa kelas I SD Negeri Gamer 02 Kota Pekalongan selama mengikuti pembelajaran menulis permulaan dengan menggunakan media kartu huruf mengalami perubahan ke arah yang lebih positif. Perilaku tersebut yaitu siswa mampu menunjukkan sikap antusias selama proses pembelajaran, siswa lebih aktif selama proses pembelajaran, siswa lebih berani dan percaya diri mempresentasikan hasil diskusi, siswa lebih termotivasi untuk menulis permulaan.

\section{Saran}

Berdasarkan simpulan hasil penelitian tersebut, saran yang diberikan peneliti adalah sebagai berikut 1) Guru hendaknya menggunakan media yang tepat dalam pembelajaran. Pembelajaran menulis permulaan menggunakan media kartu huruf telah terbukti dapat meningkatkan ketrampilan menulis permulaan. Selain itu, pembelajaran tersebut dapat mengubah perilaku siswa menjadi lebih antusias, aktif, berani dan percaya diri. 2) Bagi siswa, hendaknya lebih memperhatikan penjelasan yang diberikan guru, serius dalam belajar, dan selalu bertanya ketika menemui kesulitan dalam pembelajaran. Selain itu, siswa dapat mempraktikkan penggunaan Kartu Huruf dalam pelajaran lain dan juga harus rajin membaca dan berlatih menulis lambang bilangan dan membilang agar dapat mengembangkan kreatifitas siswa. 3) Bagi praktisi di bidang pendidikan, peneliti berharap adanya penelitian lanjutan mengenai ketrampilan menulis permulan dengan model, pendekatan, metode, teknik, dan media berdasarkan pendekatan tertentu yang tepat untuk meningkatkan keterampilan menulis permulaan. Hasil penelitian tersebut diharapkan dapat membantu guru kelas sehingga berdampak positif bagi perkembangan pendidikan yang lebih berkualitas.

\section{DAFTAR PUSTAKA}

Depdiknas. (2005). Pedoman Pembelajaran Kelas Awal Sekolah Dasar: Menciptakan Masyarakat Peduli Pendidikan Anak Program Berbasis Sekolah. Jakarta: Depdiknas.E. Kosasih, dkk.(2005).

Hartati, Tatat dkk.(2006). Pendidikan Bahasa dan Sastra Indonesia di Kelas Rendah.Bandung : UPI PRESS.

H Wahni - 2016 - Ketrampilan Menulis Permulaan,

\section{Internet}

eprints.uny.ac.id/38695/1/Wahni\%20

Hidayah.pdf

Indi Bernati, Rhapsona .(2012). Membaca Menulis Permulaan.

Nurviati, I. M. Keterampilan Menulis Untuk Siswa SD. Penerbit : Lazuardi. Jakarta. 2007.

Solchan T. W, dkk. (2008). Pendidikan Bahasa Indonesia di SD. Jakarta:Universitas Terbuka.

Yunus, M, Suparno. Keterampilan Dasar Menulis. Penerbit : Universitas Terbuka.Jakarta.2007. 